\title{
Tourniquet-ALPPS is a promising treatment for very large hepatocellular carcinoma and intrahepatic cholangiocarcinoma
}

\author{
Victor López-López ${ }^{1}$, Ricardo Robles-Campos ${ }^{1}$, Robeto Brusadin ${ }^{1}$, Asunción López- \\ Conesa ${ }^{1}$, Álvaro Navarro ${ }^{1}$, Julio Arevalo-Perez ${ }^{2}$, Pedro Jose Gil ${ }^{1}$ and Pascual Parrilla ${ }^{1}$ \\ ${ }^{1}$ Virgen de la Arrixaca Clinic and University Hospital, IMIB, Murcia, Spain \\ ${ }^{2}$ Department of Radiology, Memorial Sloan Kettering Cancer Center, New York, USA \\ Correspondence to: Ricardo Robles-Campos, email: rirocam@um.es \\ Victor López-López, email: victorrelopez@gmail.com \\ Keywords: hepatocarcinoma; intrahepatic cholangiocarcinoma; ALPPS; two-stage hepatectomy \\ Received: February 06, $2018 \quad$ Accepted: May 12, $2018 \quad$ Published: June 15, 2018 \\ Copyright: López-López et al. This is an open-access article distributed under the terms of the Creative Commons Attribution Li- \\ cense 3.0 (CC BY 3.0), which permits unrestricted use, distribution, and reproduction in any medium, provided the original author \\ and source are credited.
}

\section{ABSTRACT}

When very large hepatocellular carcinomas (HCCs) and intrahepatic cholangiocarcinoma (IHCCs) with insufficient future liver remnants are treated using associating liver partition and portal vein ligation for staged hepatectomy (ALPPS), the outcome is often poor. We therefore tested the efficacy of a modified version of that technique, tourniquet-ALPPS. A review of the literature examining outcomes of HCC and IHCC patients treated with ALPPS revealed the incidences of morbidity $\geq$ III and postoperative mortality to be respectively $20.7 \%$ and $16.1 \%$ among HCC patients and $50 \%$ and $45.4 \%$ among IHCC patients. In the present case series, in which HCC and IHCC patients were treated with tourniquet-ALPPS, median tumor size was $100 \mathbf{~ m m}$ (range: 70-200 mm). After surgical stage $I$, there was no morbidity, no mortality and the median future liver remnant had increased at day 7 by $76 \%$. In surgical stage II, $100 \%$ of tumors were resectable ( 8 right trisectionectomies, 5 with inferior vena cava resection). Two patients experienced serious morbidity $\geq$ IIIB and 1 patient died (11\%). One- and 3-year overall survival was $75 \%$ and $60 \%$, respectively. Thus tourniquet-ALPPS appears to be an effective alternative to classical ALPPS for the treatment of patients with HCC or IHCC.

\section{INTRODUCTION}

Patients with very large hepatocellular carcinoma (HCC) or intrahepatic cholangiocarcinoma (IHCC) occupying the entire right hepatic lobe require extensive liver resection but are at risk of posthepatectomy liver failure (PHLF) because they have an insufficient future liver remnant (FLR) [1-12]. In these cases, portal vein embolization (PVE) $[2,13,14]$ induces increases in volume of between $30 \%$ and $50 \%$ after $4-8$ weeks, but increases the risk of drop-out by up to $30 \%$ [13, 15-19]. On the other hand, associating liver partition and portal vein ligation for staged hepatectomy (ALPPS) [20-24] induces hypertrophy faster than PVE (by more than 60\% in only 7 days), but with higher morbidity and mortality [25-36]. Indeed, outcomes of ALPPS for malignant liver tumors are discouraging [26], with recent publications in the ALPPS Registry [36-39] reporting the poorest results for HCC, IHCC and perihilar cholangiocarcinoma (PHCC). There is thus no consensus regarding the indications for ALPPS in these cases.

We have developed an original variant of classical ALPPS, which we call "ALTPS" (associating liver tourniquet and portal vein ligation for staged hepatectomy) [40] or tourniquetALPPS [41]. This technique entails a lower surgical risk during the first stage since liver bipartition is not performed. In this report, we provide a systematic literature review of postoperative morbidity and mortality in HCC and IHCC patients treated with ALPPS and present postoperative results and oncological outcomes in cases of very large $\mathrm{HCC}$ (advanced stages of Barcelona Clinic Liver Cancer) (BCLC) [42] and IHCC 
involving the right lobe with a left insufficient FLR treated using tourniquet-ALPPS as a hypertrophy technique.

\section{RESULTS}

\section{Systematic review of the literature}

\section{Hepatocellular carcinoma}

Among a total of $101 \mathrm{HCC}$ cases reviewed (Table 1) [29, 43-62], 11 patients were female and 90 were male. Median tumor size was $8.6 \mathrm{~cm}$ (range: $3.1-19.4 \mathrm{~cm}$ ), and median age was 56 years (range $32-83$ ). The shortterm outcomes showed that among the 69 patients who were ultimately included in the bibliography review, 36 had at least one complication (52.1\%); of those 21 patients $(20.7 \%)$ had complications $\geq$ stage III. Ninetyday mortality (excluding patients from Serenari et al., for whom 1-year mortality was determined) was $16.1 \%$ (15 patients). Data extracted from the case series [43-55] showed one patient who died postoperatively, and there were no data available for one other patient.

Regarding the long-term oncological outcomes of the remaining 12 patients, one was lost during followup, and 11 were alive after 2-34 months of follow-up. In the hospital series $[29,56-62]$ and the World Registry of ALPPS publications [37, 38, 63], Overall survival (OS) and disease-free survival (DFS) ranged from 50-68.6\% and $50-87 \%$, respectively, though follow-up was less than 18 months (Table 1).

\section{Intrahepatic cholangiocarcinoma}

Of 12 patients studied in a case series [18, 57, 64-68] and hospital series [59] (Table 2), 7 were female and 5 were male. Median tumor size was $13.5 \mathrm{~cm}$ (range: $7-18 \mathrm{~cm}$ ), and the median age of the patients was 61.5 years (range: 46-72 years). Among the short-term outcomes of these patients, $11(91.6 \%)$ had postoperative complications, 6 of which were considered severe $(50 \%)$, and 5 patients died (41.6\%). Long-term oncological outcomes published in the World Registry of ALPPS series $[37,63]$ reported the OS and DFS to be $73 \%$ and $31 \%$, respectively, after 1-year of follow-up.

\section{Case series}

\section{Demographic data}

The patients included 6 men and 3 women with a median age of 60 years (range: 45-72). Median tumor size was $100 \mathrm{~mm}$ (range: $70-200 \mathrm{~mm}$ ) (Table 3). There was retrohepatic vena cava invasion (IVC) of more than 50\% of its circumference in 5 patients ( $2 \mathrm{HCC}$ and $3 \mathrm{IHCC}$ ). On patient with IHCC exhibited invasion of the right portal vein and the bile duct causing jaundice (total bilirubin: $12.3 \mathrm{mg} / \mathrm{dl}$ ), necessitating insertion of a percutaneous preoperative biliary drain.

\section{Short-term outcomes}

Surgical stage 1 was performed without the Pringle maneuver. Median blood loss was $50 \mathrm{ml}$ (range: $50-600 \mathrm{ml}$ ), and surgical time was $125 \mathrm{~min}$ (range: $90-150 \mathrm{~min}$ ). There was no morbidity or mortality, and the hospital stay was 6 days (range: $4-8$ days). Median preoperative FLR was $25 \%$ (range: $11-33 \%$ ). By postoperative day 7 , FLR had increased to $45 \%$ (range: $31-69 \%$ ). The median increase in FLR was $76 \%$ (range: $50-187.5 \%$ ), which corresponds to a daily increase of $28.5 \mathrm{ml} /$ day (range: $7.5-110.7 \mathrm{ml} /$ day). The preoperative FLR/body weight ratio increased from 0.40 (range: $0.17-0.62$ ) to 0.77 (range: $0.49-1.18$ ).

Surgical stage 2 was carried out a median of 13 days (range: 10-15 days) after stage 1, and the resectability was $100 \%$. No Pringle maneuver was needed in any case. In the 2 HCC patients with hepatitis $\mathrm{B}$ viral cirrhosis, a right hepatectomy was performed in one case and a right trisectionectomy in the other. In the remaining 7 patients, a right trisectionectomy was performed, associating caudate lobe resection and IVC resection in 5 patients $(2 \mathrm{HCC}$ and 3 IHCC) (Table 3). The median blood loss was $750 \mathrm{ml}$ (range: 100-1500 $\mathrm{ml}$ ), and 5 patients were transfused. The surgical time was $285 \mathrm{~min}$ (range: 150-360 min). The median hospital stay was 9 days (range: 5-40 days). Five patients had complications $\geq$ stage IIIA, and 2 were $\geq$ stage IIIB Table 3). Two patients presented with PHLF and fulfilled International Study Group of Liver Surgery (ISGLS) criteria grades A and C. One 58-year-old woman with IHCC died due to sepsis and PHLF. She developed acute cholangitis caused by Pseudomonas aeruginosa infection on postoperative day 20 due to stenosis of the Roux $\mathrm{H}-\mathrm{Y}$ requiring reoperation.

\section{Long-term oncological outcome}

None of the $3 \mathrm{HCC}$ patients received adjuvant treatment, whereas 3 IHCC patients received 6 cycles of gemcitabine plus cisplatin. With a median followup time of 46 months (range: 4-60 months), the 1-year and 3 -year OS were $75 \%$ and $60 \%$, respectively. During follow-up, there was a recurrence in the lung in an IHCC patient alive at 60 months and receiving chemotherapy. Two patients died during follow-up: one HCC patient with IVC resection died after 5 months due to urinary sepsis, one IHCC patient died after 25 months due to acute myocardial infarction. Three of the $4 \mathrm{HCC}$ patients remain alive after 60, 54 and 4 months, respectively; while 3 of the 5 IHCC patients remain alive after 60,54 and 8 months, respectively. 
Table 1: Literature review in hepatocellular carcinoma: clinical cases, hospital series and world registry series

\begin{tabular}{|c|c|c|c|c|c|c|c|c|c|c|c|c|}
\hline \multicolumn{13}{|l|}{$\begin{array}{l}\text { HCC } \\
\text { CLINICAL } \\
\text { CASES }\end{array}$} \\
\hline $\begin{array}{l}\text { Author } \\
\text { (reference) }\end{array}$ & Year & $\mathrm{HCC}$ & $\begin{array}{l}\text { Tumor size } \\
\text { (cm) }\end{array}$ & Ethiology & Gender & Age & Morbidity & $\begin{array}{l}\geq \text { IIIb } \\
\text { morbidity }\end{array}$ & $\begin{array}{c}\text { Type of } \\
\text { complication }\end{array}$ & $\begin{array}{c}\text { 90-day } \\
\text { mortality }\end{array}$ & $\begin{array}{c}\text { Disease-free } \\
\text { survival } \\
\text { (months) }\end{array}$ & $\begin{array}{c}\text { Overall } \\
\text { Survival } \\
\text { (months) }\end{array}$ \\
\hline Sala et al. [43] & 2012 & 1 & - & - & $\mathrm{F}$ & 77 & No & No & - & No & $\begin{array}{c}\text { No recurrence } \\
\text { (15) }\end{array}$ & Alive (15) \\
\hline $\begin{array}{l}\text { Cavaness et } \\
\text { al. [44] }\end{array}$ & 2013 & 1 & 3.4 & $\mathrm{HCV}$ & F & 57 & No & No & - & - & - & - \\
\hline $\begin{array}{l}\text { Brustia et al. } \\
\text { [45] }\end{array}$ & 2013 & 1 & - & HBV & M & 46 & Yes & Yes & $\begin{array}{l}\text { IIIB (Bile } \\
\text { leak) }\end{array}$ & No & $\begin{array}{c}\text { No recurrence } \\
\text { (8) }\end{array}$ & Alive (8) \\
\hline $\begin{array}{l}\text { Chia et al. } \\
\text { [46] }\end{array}$ & 2014 & 1 & 16 & HBV & M & 55 & No & No & - & No & $\begin{array}{l}\text { No recurrence } \\
\text { (2) }\end{array}$ & Alive (2) \\
\hline $\begin{array}{l}\text { Le Xiao et al. } \\
{[47]}\end{array}$ & 2015 & 1 & 6 & Cirrhotic & - & - & No & No & - & No & $\begin{array}{c}\text { No recurrence } \\
\text { (4) }\end{array}$ & Alive (4) \\
\hline $\begin{array}{l}\text { Romic et al. } \\
\text { [48] }\end{array}$ & 2016 & 1 & - & - & $\mathrm{F}$ & 64 & No & No & - & No & $\begin{array}{l}\text { No recurrence } \\
\text { (12) }\end{array}$ & Alive (12) \\
\hline $\begin{array}{l}\text { Cheung et al. } \\
\text { [49] }\end{array}$ & 2016 & 1 & 14 & HBV & M & 55 & No & No & - & No & $\begin{array}{l}\text { No recurrence } \\
\text { (10) }\end{array}$ & Alive (10) \\
\hline $\begin{array}{l}\text { Torres et al. } \\
\text { [50] }\end{array}$ & 2016 & 1 & 19.4 & Alcohol & M & 57 & No & No & - & No & $\begin{array}{c}\text { No } \\
\text { recurrence(3) }\end{array}$ & Alive (3) \\
\hline $\begin{array}{l}\text { Santibañes et } \\
\text { al. [51] }\end{array}$ & 2016 & 1 & 10 & Cirrhotic & F & 66 & No & No & - & No & $\begin{array}{c}\text { No recurrence } \\
\text { (8) }\end{array}$ & Alive (8) \\
\hline $\begin{array}{l}\text { Papamichail et } \\
\text { al. [52] }\end{array}$ & 2016 & 1 & 8 & Alcohol & M & 68 & Yes & No & $\begin{array}{l}\text { I (Small for } \\
\text { size) }\end{array}$ & No & $\begin{array}{c}\text { Recurrence } \\
\text { (6) }\end{array}$ & Dead (9) \\
\hline $\begin{array}{l}\text { Hong et al. } \\
{[53]}\end{array}$ & 2016 & 1 & Multiple & HBV & M & 43 & Yes & No & II (Ascites) & No & - & - \\
\hline $\begin{array}{l}\text { Chen et al. } \\
\text { [54] }\end{array}$ & 2016 & 1 & 14 & HBV & M & 43 & No & No & - & No & $\begin{array}{l}\text { No recurrence } \\
\text { (3) }\end{array}$ & Alive (3) \\
\hline \multirow[t]{2}{*}{$\begin{array}{l}\text { Sanei et al. } \\
\text { [55] }\end{array}$} & 2017 & 2 & - & - & $1 \mathrm{~F}$ & 48 & Yes & Yes & V (PTE) & Yes & - & - \\
\hline & & & - & - & $1 \mathrm{M}$ & 48 & Yes & No & $\begin{array}{c}\text { (PHLF } \\
\text { and pleural } \\
\text { effiusion) }\end{array}$ & No & $\begin{array}{c}\text { No recurrence } \\
\text { (34) }\end{array}$ & Alive (34) \\
\hline \multicolumn{13}{|l|}{ HCC SERIES } \\
\hline Author & Year & HCC & $\begin{array}{l}\text { Tumor size } \\
\text { (cm) }\end{array}$ & Ethiology & Gender & Age & Morbidity & $\begin{array}{l}\geq \text { IIIb } \\
\text { morbidity }\end{array}$ & $\begin{array}{c}\text { Type of } \\
\text { complication }\end{array}$ & $\begin{array}{c}\text { 90-day } \\
\text { mortality }\end{array}$ & $\begin{array}{c}\text { Disease-free } \\
\text { survival } \\
\text { (months) }\end{array}$ & $\begin{array}{c}\text { Overall } \\
\text { Survival } \\
\text { (months) }\end{array}$ \\
\hline $\begin{array}{l}\text { Álvarez et al. } \\
{[56]}\end{array}$ & 2015 & 3 & - & - & - & - & - & $33 \%$ & - & 33 & - & - \\
\hline $\begin{array}{l}\text { Vennarecci et } \\
\text { al. [57] }\end{array}$ & 2016 & 8 & $7.3(3.1-14)$ & - & $8 \mathrm{M}$ & $\begin{array}{c}65 \\
(36-74)\end{array}$ & $100 \%$ & $20 \%$ & - & 12.5 & - & - \\
\hline $\begin{array}{l}\text { Chan et al. } \\
\text { [58] }\end{array}$ & 2016 & 17 & $6(2.5-15)$ & - & $16 \mathrm{M}: 1 \mathrm{~F}$ & $\begin{array}{c}62 \\
(50-80)\end{array}$ & - & $11.8 \%$ & - & 5.9 & - & - \\
\hline $\begin{array}{l}\text { Björsson et al. } \\
\text { [59] }\end{array}$ & 2016 & 4 & $10.4(7-14)$ & - & $4 \mathrm{M}$ & $\begin{array}{c}74.5 \\
(68-83)\end{array}$ & $100 \%$ & $0 \%$ & - & $0 \%$ & $50 \%(8.3)$ & $50 \%(17.3)$ \\
\hline $\begin{array}{l}\text { Serenari et al. } \\
{[29]}\end{array}$ & 2016 & 8 & - & - & $6 \mathrm{M}: 2 \mathrm{~F}$ & $\begin{array}{c}56 \\
(36-74)\end{array}$ & $62.5 \%$ & $12.5 \%$ & - & $60 \%(1 \mathrm{y})$ & $75 \%(1 y)$ & $62.5 \%$ \\
\hline $\begin{array}{l}\text { Chan et al. } \\
{[60]}\end{array}$ & 2017 & 25 & $7.5(2-16)$ & - & $23 \mathrm{M}: 2 \mathrm{~F}$ & $\begin{array}{c}62 \\
(50-80)\end{array}$ & - & $16 \%$ & - & $8 \%$ & - & - \\
\hline $\begin{array}{l}\text { Wang et al. } \\
{[61]}\end{array}$ & 2017 & 10 & $\begin{array}{c}9.2 \\
(6.4-15.4)\end{array}$ & - & $9 \mathrm{M}: 1 \mathrm{~F}$ & $\begin{array}{c}41 \\
(33-60)\end{array}$ & $50 \%$ & $20 \%$ & - & $30 \%$ & $57.1 \%(7)$ & $66 \%(7)$ \\
\hline Cai et al. [62] & 2017 & 12 & $8(2.6-16)$ & & $10 \mathrm{M}: 2 \mathrm{~F}$ & $\begin{array}{c}43 \\
(32-79)\end{array}$ & $70 \%$ & $58.3 \%$ & - & $50 \%$ & $33 \%(16)$ & $66 \%(16)$ \\
\hline \multicolumn{13}{|l|}{$\begin{array}{l}\text { HCC ALPPS } \\
\text { REGISTRY }\end{array}$} \\
\hline Author & Year & HCC & $\begin{array}{c}\text { Tumor size } \\
\text { (cm) }\end{array}$ & Ethiology & Gender & Age & Morbidity & $\begin{array}{c}\geq \text { IIIA } \\
\text { morbidity }\end{array}$ & $\begin{array}{c}\text { Type of } \\
\text { complication }\end{array}$ & $\begin{array}{c}\text { 90-day } \\
\text { mortality }\end{array}$ & $\begin{array}{c}\text { Disease-free } \\
\text { survival } \\
\text { (months) }\end{array}$ & $\begin{array}{l}\text { Overall } \\
\text { Survival } \\
\text { (months) }\end{array}$ \\
\hline $\begin{array}{l}\text { Schadde et al. } \\
\text { [37] }\end{array}$ & 2014 & $17(8 \%)$ & - & - & - & - & - & $25 \%$ & - & $12 \%$ & $\begin{array}{c}87 \% \\
\text { (at } 1 \text { year) }\end{array}$ & $\begin{array}{c}61 \% \\
\text { (at } 1 \text { year) }\end{array}$ \\
\hline
\end{tabular}




\begin{tabular}{|c|c|c|c|c|c|c|c|c|c|c|c|c|}
\hline $\begin{array}{l}\text { Schadde et al. } \\
\text { [63] }\end{array}$ & 2015 & $\begin{array}{c}32 \\
(10 \%)\end{array}$ & - & - & - & - & - & $44 \%$ & - & $13 \%$ & - & - \\
\hline $\begin{array}{l}\text { D'Haese et al. } \\
\text { [38] }\end{array}$ & 2015 & $\begin{array}{c}35 \\
(15.5 \%)\end{array}$ & - & - & - & - & $62.9 \%$ & $26.9 \%$ & - & $31.4 \%$ & $60 \%$ (at $18 \mathrm{~m}$ ) & $\begin{array}{c}68.6 \% \\
\text { (at } 18 \mathrm{~m} \text { ) }\end{array}$ \\
\hline
\end{tabular}

HCC: hepatocellular carcinoma; F: female; M: male; PHLF: postoperative hepatic liver failure; PTE: Pulmonary thromboembolism.

Table 2: Literature review for intrahepatic cholangiocarcinoma: clinical cases, hospital series and world registry series

\begin{tabular}{|c|c|c|c|c|c|c|c|c|c|c|c|}
\hline $\begin{array}{l}\text { IHCC CLINICAL } \\
\text { CASES }\end{array}$ & & & & & & & & & & & \\
\hline Author & Year & $N$ & $\begin{array}{c}\text { Tumor } \\
\text { size } \\
\text { (cm) }\end{array}$ & Gender & Age & Morbidity & $\begin{array}{c}\geq \text { IIIB } \\
\text { morbidity }\end{array}$ & $\begin{array}{c}\text { Type } \\
\text { of complication }\end{array}$ & $\begin{array}{l}\text { 90-day } \\
\text { mortality }\end{array}$ & $\begin{array}{c}\text { Disease -free } \\
\text { Survival } \\
\text { (months) }\end{array}$ & $\begin{array}{c}\text { Overall } \\
\text { Survival } \\
\text { (months) }\end{array}$ \\
\hline Troja et al. [64] & 2014 & 1 & - & F & 72 & Yes & Yes & $\begin{array}{l}\text { V (Death, } \\
\text { hemorragic } \\
\text { shock) }\end{array}$ & Yes & - & - \\
\hline Oldhafer et al. [65] & 2015 & 1 & - & M & 46 & Yes & No & II. Ascites & Yes & $\begin{array}{l}\text { Recurrence } \\
\text { (1) }\end{array}$ & $\begin{array}{l}\text { Dead } \\
(2.5)\end{array}$ \\
\hline Vicente et al. [66] & 2015 & 1 & - & - & 62 & Yes & Yes & $\begin{array}{c}\text { IVA } \\
\text { (Biliary leak) }\end{array}$ & No & - & - \\
\hline \multirow{2}{*}{$\begin{array}{l}\text { Vennarecci } \\
\text { et al. [57] }\end{array}$} & \multirow[b]{2}{*}{2016} & \multirow[b]{2}{*}{2} & 15 & $1 \mathrm{~F}$ & 60 & Yes & Yes & V (Death, sepsis) & Yes & - & - \\
\hline & & & 12 & $1 \mathrm{M}$ & 54 & Yes & Yes & V (Death, sepsis) & Yes & - & - \\
\hline \multirow[b]{2}{*}{ Ulmer et al. [18] } & \multirow[b]{2}{*}{2016} & \multirow[b]{2}{*}{2} & - & $1 \mathrm{M}$ & 72 & Yes & Yes & $\begin{array}{c}\text { IIIA } \\
\text { (Biliary leak) }\end{array}$ & No & - & - \\
\hline & & & - & $1 \mathrm{~F}$ & 72 & Yes & Yes & $\begin{array}{c}\mathrm{V} \\
\text { (Pneumonia, } \\
\text { Sepsis) }\end{array}$ & Yes & - & - \\
\hline Lai et al. [67] & 2017 & 1 & 18 & $\mathrm{~F}$ & 50 & No & No & & No & $\begin{array}{l}\text { No } \\
\text { recurrence } \\
\text { (3) }\end{array}$ & Alive (3) \\
\hline Pineda-Solís [68] & 2017 & 1 & - & $\mathrm{F}$ & 44 & Yes & No & $\begin{array}{c}\text { IIIA } \\
\text { (Pneumonia, } \\
\text { sepsis) }\end{array}$ & No & - & - \\
\hline \multicolumn{12}{|l|}{$\begin{array}{l}\text { IHCC HOSPITAL } \\
\text { SERIES }\end{array}$} \\
\hline Author & Year & $N$ & $\begin{array}{c}\text { Tumor } \\
\text { size } \\
(\mathrm{cm})\end{array}$ & Gender & Age & Morbidity & $\begin{array}{c}\geq \text { IIIB } \\
\text { morbidity }\end{array}$ & $\begin{array}{c}\text { Type of } \\
\text { complication }\end{array}$ & $\begin{array}{l}\text { 90-day } \\
\text { mortality }\end{array}$ & $\begin{array}{c}\text { Disease - } \\
\text { free } \\
\text { Survival } \\
\text { (months) }\end{array}$ & $\begin{array}{c}\text { Overall } \\
\text { Survival } \\
\text { (months) }\end{array}$ \\
\hline Björsson et al. [46] & 2016 & 3 & $\begin{array}{c}10.4 \\
(7-14)\end{array}$ & $1 \mathrm{M}: 2 \mathrm{~F}$ & $\begin{array}{c}67 \\
(61-70)\end{array}$ & $100 \%$ & $0 \%$ & - & - & $0 \%$ & $66 \%(18)$ \\
\hline \multicolumn{12}{|l|}{$\begin{array}{l}\text { IHCC ALPPS } \\
\text { REGISTRY }\end{array}$} \\
\hline Author & Year & $N$ & $\begin{array}{c}\text { Tumor } \\
\text { size } \\
(\mathrm{cm})\end{array}$ & Gender & Age & Morbidity & $\begin{array}{c}\geq \text { IIIB } \\
\text { morbidity }\end{array}$ & $\begin{array}{c}\text { Type of } \\
\text { complication }\end{array}$ & $\begin{array}{l}\text { 90-day } \\
\text { mortality }\end{array}$ & $\begin{array}{l}\text { Disease - } \\
\text { free } \\
\text { Survival } \\
\text { (months) }\end{array}$ & $\begin{array}{c}\text { Overall } \\
\text { Survival } \\
\text { (months) }\end{array}$ \\
\hline Schadde et al. [37] & 2014 & $8(4 \%)$ & - & - & - & - & $43 \%$ & - & $13 \%$ & $\begin{array}{c}31 \% \text { (at } 1 \\
\text { year) }\end{array}$ & $\begin{array}{c}73 \% \text { (at } 1 \\
\text { year) }\end{array}$ \\
\hline Schadde et al. [63] & 2015 & $13(4 \%)$ & - & - & - & - & $38 \%$ & - & $15 \%$ & - & - \\
\hline
\end{tabular}

IHCC: intrahepatic cholangiocarcinoma; F: female; M: male.

\section{DISCUSSION}

Currently available evidence indicates the incidence of morbidity and mortality is high among HCC and IHCC patients treated using ALPPS $[26,27,38,49,50,52,54$,
$57,58,69,70]$. In the first edition of the ALPPS World Registry [37], the 90-day mortality was reported to be $9 \%$, but it was higher for HCC (12\%), IHCC (13\%), perihiliar cholangiocarcinoma $(27 \%)$ and gallbladder carcinoma (33\%) than in cases of colorectal liver metastasis (CRLM) 
Table 3: Demographic, volumetric, tumor, surgical and postoperative data of hospital series

\begin{tabular}{|c|c|c|c|c|c|c|c|c|c|}
\hline & Case 1 & Case 2 & Case 3 & Caso 4 & Case 5 & Case 6 & Case 7 & Case 8 & Case 9 \\
\hline $\begin{array}{l}\text { Type of } \\
\text { tumor }\end{array}$ & $\mathrm{HCC}$ & $\mathrm{HCC}$ & $\mathrm{HCC}$ & $\mathrm{HCC}$ & $\mathrm{IHCC}$ & IHCC & IHCC & IHCC & IHCC \\
\hline Age (years) & 45 & 71 & 68 & 52 & 60 & 58 & 60 & 72 & 57 \\
\hline Gender & Male & Male & Male & Male & Female & Female & Female & Male & Male \\
\hline Histology & $\begin{array}{c}\text { Grade } 2 / 6 \\
\text { fibrosis }\end{array}$ & $\begin{array}{l}\text { Grade } 2 / 6 \\
\text { fibrosis }\end{array}$ & $\begin{array}{l}\text { Cirrhosis } \\
\text { B virus }\end{array}$ & $\begin{array}{l}\text { Cirrhosis } \\
\text { B virus }\end{array}$ & Normal & Cholestasis & Normal & Normal & Normal \\
\hline $\begin{array}{l}\text { Tumor size } \\
\left(n^{0} \text { nodules) }\right.\end{array}$ & $200(1)$ & $120(1)$ & $\begin{array}{c}70+40^{*} \\
(2)\end{array}$ & $160(1)$ & $130(1)$ & $100(1)$ & $120(1)$ & $70(1)$ & $87(1)$ \\
\hline BMI & 27.4 & 25 & 33 & 26 & 24 & 29.7 & 32.4 & 32.5 & 24.6 \\
\hline $\begin{array}{l}\text { Charlson } \\
\text { index }\end{array}$ & 2 & 8 & 10 & 11 & 2 & 11 & 11 & 10 & 5 \\
\hline MELD & 9 & 8 & 7 & 9 & 7 & 7 & 8 & 7 & 6 \\
\hline $\begin{array}{l}\text { Neoadjuvant } \\
\text { treatment }\end{array}$ & TACE & TACE & TACE & TACE & No & No & No & No & No \\
\hline $\begin{array}{l}\text { Preoperative } \\
\text { FLR }(\%)\end{array}$ & 24 & 29 & 33 & 25 & 29 & 11 & 13 & 25 & 25 \\
\hline $\begin{array}{l}\text { FLR Before } \\
\text { Stage II (\%) }\end{array}$ & 69 & 44 & 47 & 48 & 60 & 31 & 39 & 44 & 45 \\
\hline IFLR (\%) & 187.5 & 51.7 & 42.4 & 105 & 76 & 182 & 200 & 76 & 50 \\
\hline $\begin{array}{l}\text { Stage II } \\
\text { surgical tech. }\end{array}$ & $\begin{array}{l}\mathrm{RT}+ \\
\mathrm{IVCR}\end{array}$ & $\mathrm{RT}+\mathrm{IVCR}$ & RH & RT & RT + IVCR & $\begin{array}{c}\text { RT + } \\
\text { IVCR+ } \\
\text { PV+ Roux- } \\
\text { HY }\end{array}$ & $\begin{array}{l}\mathrm{RT}+ \\
\mathrm{IVCR}\end{array}$ & RT & RT \\
\hline $\begin{array}{l}\text { Morbidity } \\
\text { stage II } \\
\text { (Clavien- } \\
\text { Dindo) }\end{array}$ & No & $\begin{array}{c}\text { Chylothorax } \\
\text { (IIIA) }\end{array}$ & $\begin{array}{c}\text { Abscess } \\
\text { (IIIB) }\end{array}$ & $\begin{array}{l}\text { Ascites } \\
\text { (II) }\end{array}$ & $\begin{array}{c}\text { Chylothorax } \\
\text { (IIIA) }\end{array}$ & $\begin{array}{l}\text { Sepsis. } \\
\text { PHLF } \\
\text { (V) }\end{array}$ & No & No & $\begin{array}{c}\text { Abscess } \\
\text { IIIA }\end{array}$ \\
\hline $\begin{array}{l}\text { Transfusion } \\
\text { stage II (ml) }\end{array}$ & 1500 & 1200 & No & 300 & 600 & 1200 & 900 & No & No \\
\hline $\begin{array}{l}\text { Follow-up } \\
\text { (months) }\end{array}$ & Alive (60) & Died (5) & Alive (54) & Alive (4) & Alive (60) & Died (1) & $\begin{array}{l}\text { Died } \\
(25)\end{array}$ & $\begin{array}{c}\text { Alive } \\
(54)\end{array}$ & $\begin{array}{l}\text { Alive } \\
(8)\end{array}$ \\
\hline
\end{tabular}

HCC: hepatocellular carcinoma; IHCC: intrahepatic cholangiocarcinoma; IVCR: inferior vena cava resection; RPV: right portal vein; RT: right Trisectionectomy; RH: right hepatectomy; BMI: body mass index; TACE: transarterial chemoembolization; FLR: future liver remnant; IFLR: increase of future liver remnant volume. PHLF: postoperative hepatic liver failure. ${ }^{*}$ Both nodules in the right lobe.

$(8 \%)$. For that reason, subsequent editions of the ALPPS World Registry attempted to identify factors contributing to a poor prognosis, either preoperatively or after the first surgical stage, in order to prevent futile second interventions $[39,63]$.

Treatment of early stage $\mathrm{HCC}$ is liver resection or transplantation, whereas for patients with BCLS stage B $\mathrm{HCC}$, the recommended treatment is TACE or palliative treatment. However, recent reports suggest surgical treatment can achieve prolonged survival in advanced
HCC patients [71, 42, 72-74], even patients with IVC invasion, as occurred in a patient in this series (60 months survival). These findings may justify an aggressive surgical approach and support the use of ALPPS in patients with BCLC stage B HCC. However, D'Haese et al. [38] reported higher 90-day mortality among HCC patients than among those with CRLM (31\% vs. 7\%). They concluded that the risk associated with ALPPS remains prohibitive for most $\mathrm{HCC}$ patients and that ALPPS should only be performed in a highly select group 
of HCC patients younger than 60 years and with a low fibrosis grade. Similar results were obtained by Vennarecci et al. [57], who reported a postoperative mortality rate of $23.1 \%$. In our literature review, we also found mortality to be high among both HCC (16.1\%) and IHCC (45.4\%) patients treated with ALPPS.

Several alternatives to the classical technique have been developed in an effort to reduce ALPPS-related morbidity [30, 40, 51, 53, 61, 75-78], especially to reduce the aggressiveness of stage 1 . We started using tourniquetALPPS in our Department in 2011. With this technique, stage 1 does not include bipartition of the liver so as to minimize blood loss and substantially shorten the surgical time. In the present series, despite the large size of their tumors, no patient experienced any complications after stage 1 , and all achieved sufficient hypertrophy after 7 days to perform stage 2, with no tumor progression. To avoid tumor growth after surgical stage 1, 4 HCC patients we administered 2 sessions of preoperative transarterial chemoembolization (TACE). The surgery in stages 1 and 2 was performed without using the Pringle maneuver, which is used in $24 \%$ of patients treated with ALPPS [37]. This is because liver partition was not performed in surgical stage 1 , and in stage 2 the bipartition was carried out on the ischemic line left by the tourniquet. During stage 2, 5 patients were transfused but this was mainly related to the extreme liver surgery performed with complete IVC resection.

ALPPS-related mortality is also decreasing (from $17 \%$ to $4 \%$ in 2015 ), especially at centers with experience in the technique. Independent factors associated with mortality include risk adjustment in patient selection $(P<0.001)$ and use of less invasive techniques in stage 1 surgery $(P=0.019)$ [77]. Although our small sample size is a limitation, it is noteworthy that there was no mortality among the HCC patients in the present series, despite performance of a more aggressive surgical technique. The only patient who died was diagnosed with IHCC with portal vein and IVC invasion, who was a high-risk patient due to preoperative jaundice and Roux H-Y anastomosis.

Theoretically, HCC has a lower regenerative capacity because it usually arises against a background of cirrhosis or fibrosis. However, an earlier study showed that ALPPS is technically feasible and safe in HCC patients with cirrhosis, in whom it induces significant volume increases [57, 79]. D'Haese et al. [38] reported that hypertrophy was lower in HCC patients than in CRLM patients (47 vs. $76 \% ; p<0.002$ ) and was negatively correlated with the degree of fibrosis. But surprisingly, Vennarecci et al. [57] found that hypertrophy at 7 days was greater in cirrhotic patients than in normal liver $(71.7 \%$ vs $64.8 \%$, respectively). In the $3 \mathrm{HCC}$ patients treated with tourniquet-ALPPS, the increase was $187.5 \%, 51.7 \%$, and $42.4 \%$, respectively.

There is currently no general recommendation about adjuvant chemotherapy for IHCC [80, 81]. Some authors suggest adjuvant chemotherapy in cases with lymphovascular and perineural invasion or positive resection margins. In the present study, the decision in favor of adjuvant chemotherapy (gemcitabine/cisplatin) was taken by our interdisciplinary tumor board considering tumor staging (large tumors and IVC invasion).

D'Haese et al. [38] reported that after ALPPS, OS for HCC patients was significantly shorter than for CRLM patients, with a DFS of 8 months for CRLM and 12 months for HCC. In a study from Vennarecci et al. [57], who reported only a short median follow-up (15 months), the 1-year OS and DFS for HCC were $74 \%$ and $42 \%$, respectively. The median DFS was only 9 months, and 3 of $8 \mathrm{HCC}$ patients experienced tumoral recurrence. Schadde et al. [37] reported a 1 -year OS of $61 \%$ for HCC. The results for IHCC were worse, with a 1-year DFS rates of $31 \%$ (with R0 resectability of $86 \%$ ). In the present series with tourniquet-ALPPS, 1- and 3-year OS for IHCC were $75 \%$ and $60 \%$, respectively. One patient experienced recurrence in the lung at 50 months, but is alive at 60 months and is currently receiving chemotherapy. In the literature review, with a follow-up of less than 18 months for both HCC and IHCC, DFS was 50\% and 31\%, respectively.

This study has several limitations in line with previously published articles. They are related primarily to its retrospective nature and small sample. In the present study, however, patients received more aggressive treatment due to the higher rate of IVC resection than in previously published studies.

In conclusion, despite the aforementioned limitations, tourniquet-ALPPS appears to be a feasible option for treatment of patients with HCC beyond BCLC classification and with IHCC frequently involving the IVC. Tourniquet-ALPPS induces sufficient hypertrophy after 7 days with no tumor progression, and it enables acceptable long-term outcomes. More studies with larger numbers of patients are needed to confirm these results.

\section{METHODS}

\section{Systematic review}

A systematic review of the English language literature was performed based on recommendations of the Preferred Reporting Items for Systematic Reviews and Meta-analyses (PRISMA) statement [84], the Strengthening the Reporting of Observational Studies in Epidemiology statement [82], and the Assessment of Multiple Systematic Reviews tool [83].

\section{Information sources and database searching}

A medical librarian developed the systematic strategy utilized to search the Medline/PubMed, EMBASE, Scopus, ClinicalTrials.gov, the Cochrane 
Database of Systematic Reviews and the Cochrane Central Register of Controlled Trials. The search terms included a combination of standardized index terms and plain language to cover the terms "ALPPS", "associating liver partition and portal vein ligation for staged hepatectomy" and "in situ split" as comprehensively as possible. Searches were limited to studies published in English using the standard limitations provided by the respective databases. Key review articles were identified, and their reference lists examined for relevant articles. The final search was performed in July 2017. Two researchers (VL \& AN) independently screened bibliographies of relevant review articles and publications in the field. The same two researchers together screened titles and abstracts from the publications. In the event of disagreement, a third reviewer (RR) was involved. Refer to Figure 1 for a detailed flow schema, which was in accord with PRISMA guidelines.

\section{Quality assessment}

Study quality was assessed with the Cochrane risk of bias tool [84] using the following domains: sequence generation and allocation concealment; performance and detection bias; incomplete outcome data; selective outcome reporting; and other bias. Understandably, it is not feasible to conduct fully blinded studies for this research question, as both the patients and staff know the nature of the intervention. Given these difficulties, if a study did not mention any blinding of staff or patients and it was not possible to contact the authors, the study was assumed to be unblinded and therefore at high risk of performance and detection bias. It was, however, possible for detection bias to be reduced by using standardized criteria for complications and discharge and for outcome assessors to be unaware of the patients' allocation.

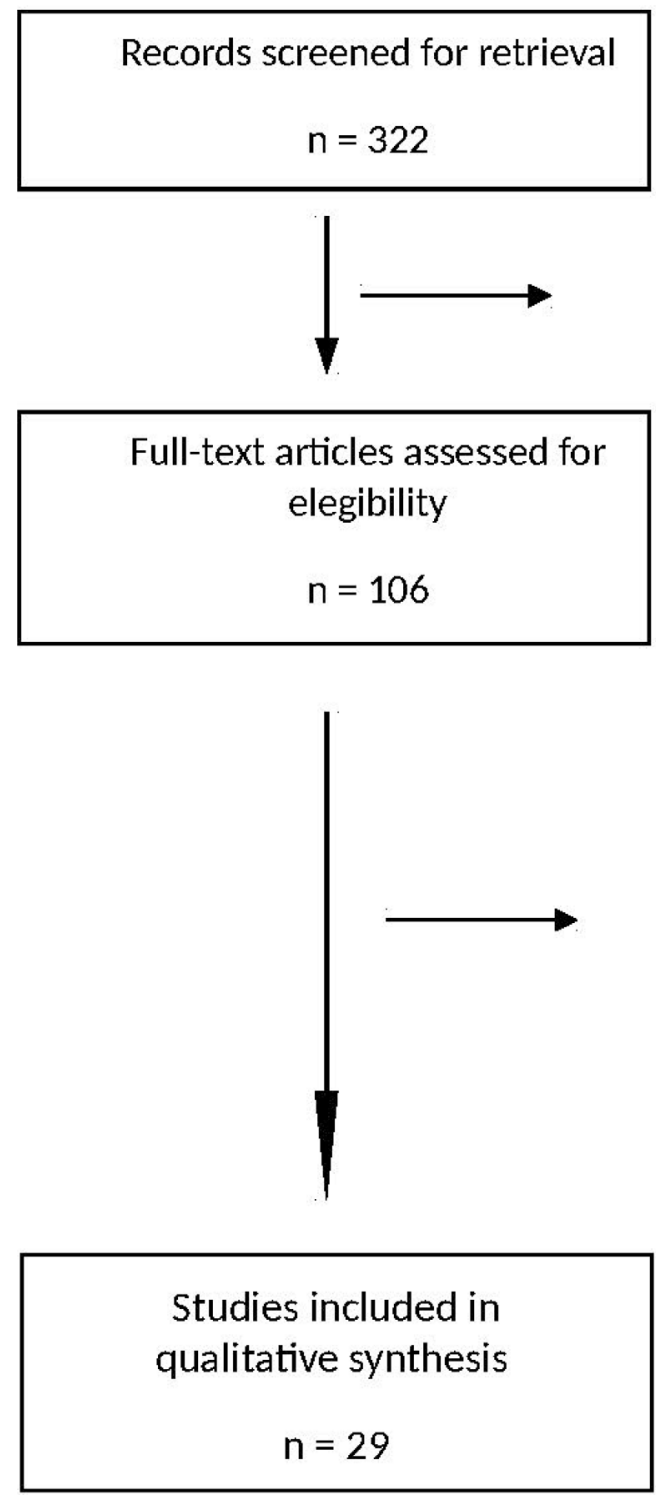

Full-text articles exluded $n=77$

Unrelated to review questions $n=48$

Letter/editorial $n=12$

Non-English Lenguage $n=9$

Redundat publication from the same institution $n=8$

Figure 1: Modified PRISMA flow diagram of studies considered for inclusion in the systematic review. 


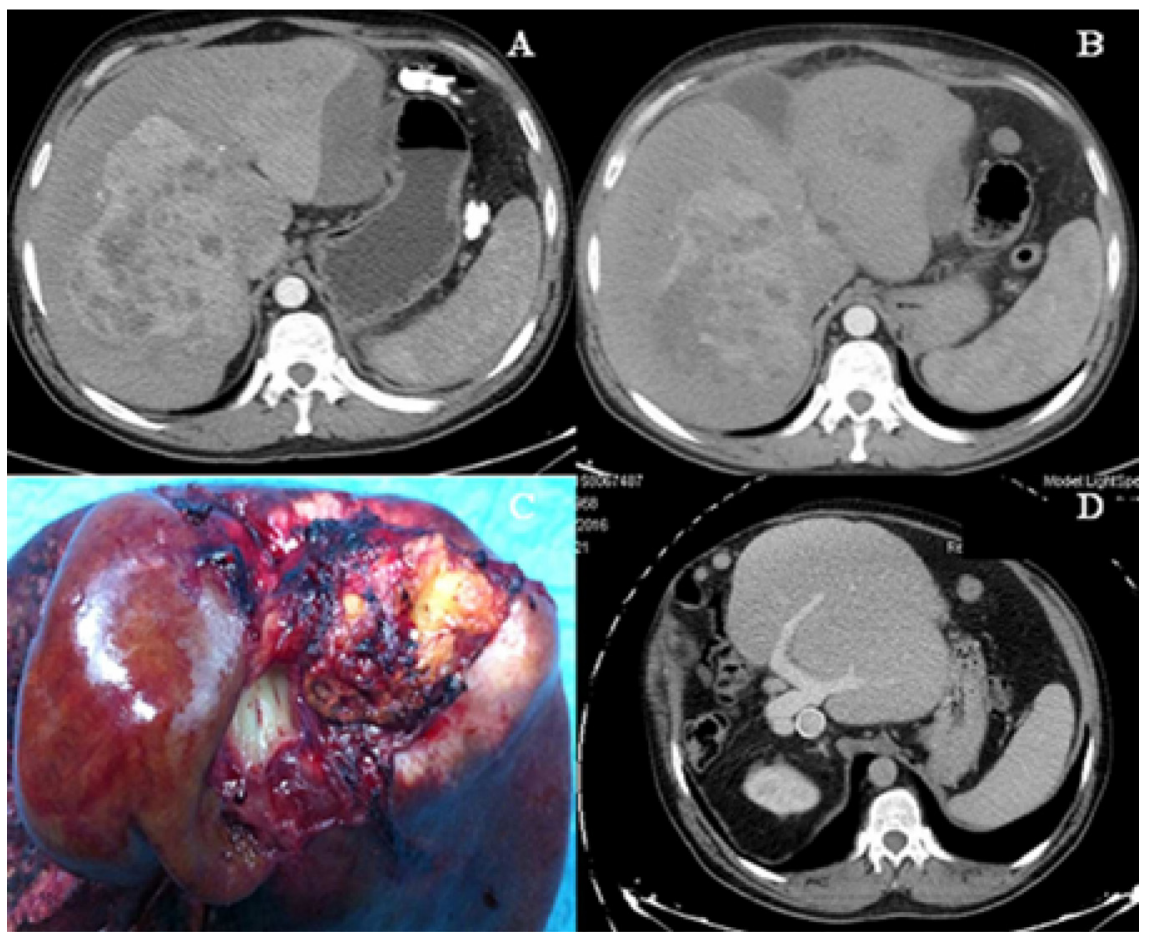

Figure 2: (A) Very large HCC with grade 2/6 fibrosis beyond the BCLC classification and inferior vena cava invasion; cirrhosis was ruled out, but subcapsular hematoma in the left lobe was detected. (B) CT volumetry on day 7 after stage I, with a future liver remnant increase of $187 \%$. (C) Right trisectionectomy with inferior vena cava resection involving the caudate. (D) Follow-up CT at 60 months shows a diseasefree liver with the vena cava graft still permeable.

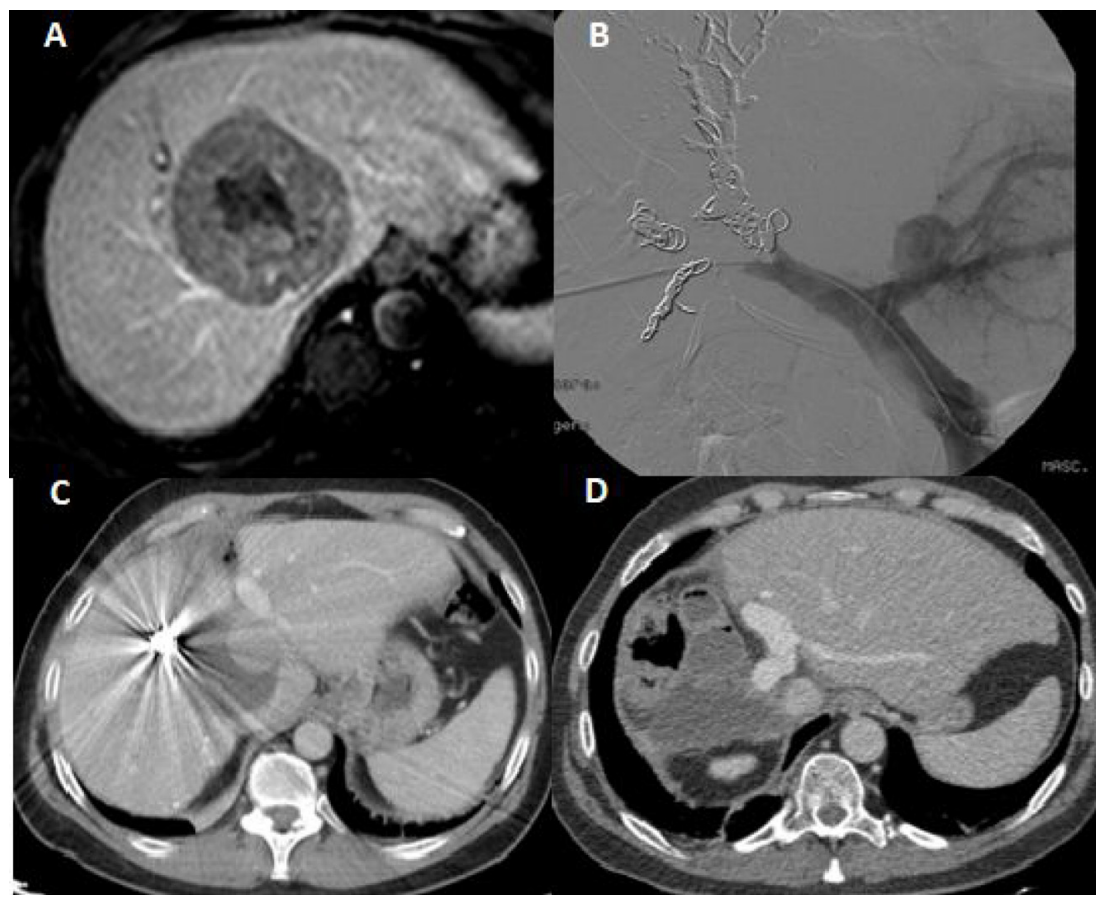

Figure 3: (A) Very large HCC with hepatitis B viral cirrhosis involving the right hepatic lobe. CT image depicting very large HCC involving the middle and right hepatic vein. (B) On day 4 after tourniquet placement during the first stage, we performed a right portal vein embolization. (C) CT volumetry on day 9 after stage I showing a future liver remnant increase of 105\%. (D) Follow-up CT at 4 months shows the disease-free liver after right trisectionectomy. 


\section{Data extraction}

Data were systematically extracted under the following headings: Study Design (e.g., Randomized Controlled trial, Registry review, Cohort study, etc), Study Population (Dates of recruitment, Number of patients, Age, Sex), Indications for HCC and IHCC, Surgical Procedures performed, morbidity, mortality and follow-up period.

\section{Data synthesis}

Data synthesis was performed using narrative methods. Because of the small number of studies assessed for methodological quality and the variety of outcome measures used, a meta-analysis was not possible.

\section{Case series}

\section{Patient selection}

Between September 2011 and July 2017, we performed one classical ALPPS and 50 tourniquetALPPS. Among the patients treated with tourniquetALPPS, 9 with HCC or IHCC were included in this study. Informed consent to be included in the study was obtained from all study participants. Tumor staging was carried out using the corresponding tumor markers (CEA, Ca 19.9, alpha-fetoprotein), CT (Figures 2 and 3), MRI and PET-scan. Exclusion criteria included the presence of extrahepatic disease and poor performance status (ECOG $\geq 2$, ASA IV). Patients with HCC underwent TACE [85]. We assessed 90-day morbidity and mortality and longterm results. Morbidity was classified using ClavienDindo criteria [86], while PHLF was classified using ISGLS criteria [87].

Total liver volume (TLV), tumor volume, FLR ( $\mathrm{ml}$ and percentage) and the FLR/body weight ratio were calculated. A FLR lower than $25 \%$ in patients with healthy livers or less than $50 \%$ in cirrhotic patients with intermediate stage or Child A cirrhosis were considered insufficient. A FLR/body weight ratio of less than 0.5 in patients with a healthy liver or less than 0.7 in those with a cirrhotic liver was considered insufficient.

\section{Surgical technique}

Tourniquet-ALPPS has been described previously [40]. In stage 1, after ligation of the right portal vein, we do not perform the liver partition. The tourniquet is placed within the umbilical fissure or main portal fissure and is tightened enough to occlude vascular communication between both lobes (which avoids liver transection but leads to the desired liver hypertrophy before resection is performed). The patients can usually be discharged a few days after the first stage. CT scan volumetry is performed on the 7th postoperative day (Figures 2 and 3 ) to assess the increase in FLR and FLR/body weight ratio.
In stage 2, we use the inserted tourniquet as an aid for the hanging maneuver, after which liver bipartition is performed using an anterior and in situ approach along the ischemic line caused by the tourniquet. In case of IVC invasion, after resection of the IVC, it was replaced with a $2-\mathrm{cm}$ ringed Gore-Tex ${ }^{\circledR}$ graft $\left(\right.$ Gore $^{\circledR}$, Newark, DE, USA) (Figure 2). Once the patients recovered from the surgery, those with IHCC received adjuvant chemotherapy in consultation with an oncologist. No patient with HCC received adjuvant chemotherapy.

\section{Statistical analysis}

Statistical analysis was carried out using SPSS Statistics 22.0 software (SPSS Inc., Chicago, IL, USA). Kaplan-Meier curves were used for survival assessment.

\section{Author contributions}

Ricardo Robles: Study conception and design, acquisition of data, analysis and interpretation of data, drafting of manuscript, critical revision of manuscript. Roberto Brusadin: Study conception and design, acquisition of data, analysis and interpretation of data, drafting of manuscript, critical revision of manuscript. Asunción Lopez-Conesa: Study conception and design, analysis and interpretation of data, drafting of manuscript. Victor López-López: Study conception and design, acquisition of data, analysis and interpretation of data, drafting of manuscript, critical revision of manuscript. Álvaro Navarro: Study conception and design, acquisition of data, analysis and interpretation of data, drafting of manuscript, critical revision of manuscript. Julio ArevaloPerez: Study conception and design and drafting of manuscript. Pedro Gil: Study conception and design, acquisition of data, analysis and interpretation of data. Pacual Parrilla: Study conception and design, drafting of manuscript, critical revision of manuscript.

\section{CONFLICTS OF INTEREST}

The authors declare that they have no conflicts of interest.

\section{FUNDING}

The authors declare that they have no financial support.

\section{REFERENCES}

1. Jarnagin WR, Gonen M, Fong Y, DeMatteo RP, BenPorat L, Little S, Corvera C, Weber S, Blumgart LH. Improvement in perioperative outcome after hepatic resection: analysis of 1,803 consecutive cases over the past 
decade. Ann Surg. 2002; 236:397-406; discussion 406-7. https://doi.org/10.1097/01.sla.0000029003.66466.b3.

2. Makuuchi M, Thai BL, Takayasu K, Takayama T, Kosuge T, Gunven P, Yamazaki S, Hasegawa H, Ozaki H. Preoperative portal embolization to increase safety of major hepatectomy for hilar bile duct carcinoma: a preliminary report. Surgery. 1990; 107:521-7.

3. Adam R, Laurent A, Azoulay D, Castaing D, Bismuth H. Two-stage hepatectomy: A planned strategy to treat irresectable liver tumors. Ann Surg. 2000; 232:777-85.

4. Liu H, Zhu S. Present status and future perspectives of preoperative portal vein embolization. Am J Surg. 2009; 197:686-90. https://doi.org/10.1016/j.amjsurg.2008.04.022.

5. Aussilhou B, Lesurtel M, Sauvanet A, Farges O, Dokmak S, Goasguen N, Sibert A, Vilgrain V, Belghiti J. Right portal vein ligation is as efficient as portal vein embolization to induce hypertrophy of the left liver remnant. J Gastrointest Surg. 2008; 12:297-303. https://doi.org/10.1007/s11605-007-0410-x.

6. Honjo I, Suzuki T, Ozawa K, Takasan H, Kitamura O. Ligation of a branch of the portal vein for carcinoma of the liver. Am J Surg. 1975; 130:296-302.

7. Kinoshita H, Sakai K, Hirohashi K, Igawa S, Yamasaki O, Kubo S. Preoperative portal vein embolization for hepatocellular carcinoma. World J Surg. 1986; 10:803-8.

8. Nagino M, Kamiya J, Kanai M, Uesaka K, Sano T, Yamamoto H, Hayakawa N, Nimura Y. Right trisegment portal vein embolization for biliary tract carcinoma: technique and clinical utility. Surgery. 2000; 127:155-60. https://doi.org/10.1067/msy.2000.101273.

9. Nagino M, Kamiya J, Nishio H, Ebata $T$, Arai $T$, Nimura Y. Two hundred forty consecutive portal vein embolizations before extended hepatectomy for biliary cancer: surgical outcome and longterm follow-up. Ann Surg. 2006; 243:364-72. https://doi.org/10.1097/01.sla.0000201482.11876.14.

10. Bartsch F, Heinrich S, Lang H. Limits of Surgical Resection for Bile Duct Cancer. Viszeralmedizin. 2015; 31:189-93. https://doi.org/10.1159/000433482.

11. Madoff DC, Hicks ME, Abdalla EK, Morris JS, Vauthey JN. Portal vein embolization with polyvinyl alcohol particles and coils in preparation for major liver resection for hepatobiliary malignancy: safety and effectiveness-study in 26 patients. Radiology. 2003; 227:251-60. https://doi.org/10.1148/radiol.2271012010.

12. Nakanishi Y, Tsuchikawa T, Okamura K, Nakamura T, Tamoto E, Noji T, Asano T, Amano T, Shichinohe T, Hirano S. Risk factors for a high Comprehensive Complication Index score after major hepatectomy for biliary cancer: a study of 229 patients at a single institution. HPB (Oxford). 2016; 18:735-41. https://doi.org/10.1016/j.hpb.2016.06.013.

13. Shindoh J, Vauthey JN, Zimmitti G, Curley SA, Huang SY, Mahvash A, Gupta S, Wallace MJ, Aloia TA. Analysis of the efficacy of portal vein embolization for patients with extensive liver malignancy and very low future liver remnant volume, including a comparison with the associating liver partition with portal vein ligation for staged hepatectomy approach. J Am Coll Surg. 2013; 217:126-33; discussion 33-4. https://doi.org/10.1016/j.jamcollsurg.2013.03.004.

14. Robles R, Marin C, Lopez-Conesa A, Capel A, PerezFlores D, Parrilla P. Comparative study of right portal vein ligation versus embolisation for induction of hypertrophy in two-stage hepatectomy for multiple bilateral colorectal liver metastases. Eur J Surg Oncol. 2012; 38:586-93. https://doi.org/10.1016/j.ejso.2012.03.007.

15. Nagino M, Nimura Y, Kamiya J, Kanai M, Uesaka K, Goto Y, Hayakawa N, Yamamoto H, Kondo S. Preoperative transhepatic portal vein embolization for impaired residual hepatic function in patients with obstructive jaundice. Journal of Hepato-Biliary-Pancreatic Surgery. 1997; 4:373-6. https://doi.org/10.1007/BF02488968.

16. Pamecha V, Levene A, Grillo F, Woodward N, Dhillon A, Davidson BR. Effect of portal vein embolisation on the growth rate of colorectal liver metastases. Br J Cancer. 2009; 100:617-22. https://doi.org/10.1038/sj.bjc.6604872.

17. Enne M, Schadde E, Bjornsson B, Hernandez Alejandro R, Steinbruck K, Viana E, Robles Campos R, Malago M, Clavien PA, De Santibanes E, Gayet B. ALPPS as a salvage procedure after insufficient future liver remnant hypertrophy following portal vein occlusion. HPB (Oxford). 2017; 19:1126-1129. https://doi.org/10.1016/j.hpb.2017.08.013.

18. Ulmer TF, de Jong C, Andert A, Bruners P, Heidenhain CM, Schoening W, Schmeding M, Neumann UP. ALPPS Procedure in Insufficient Hypertrophy After Portal Vein Embolization (PVE). World J Surg. 2017; 41:250-7. https://doi.org/10.1007/s00268-016-3662-3.

19. Sparrelid E, Gilg S, Brismar TB, Lundell L, Isaksson B. Rescue ALPPS is efficient and safe after failed portal vein occlusion in patients with colorectal liver metastases. Langenbecks Arch Surg. 2017; 402:69-75. https://doi.org/10.1007/s00423-016-1524-y.

20. Schnitzbauer AA, Lang SA, Goessmann H, Nadalin S, Baumgart J, Farkas SA, Fichtner-Feigl S, Lorf T, Goralcyk A, Horbelt R, Kroemer A, Loss M, Rummele P, et al. Right portal vein ligation combined with in situ splitting induces rapid left lateral liver lobe hypertrophy enabling 2-staged extended right hepatic resection in small-for-size settings. Ann Surg. 2012; 255:405-14. https://doi.org/10.1097/SLA.0b013e31824856f5.

21. de Santibanes E, Clavien PA. Playing Play-Doh to prevent postoperative liver failure: the "ALPPS" approach. Ann Surg. 2012; 255:415-7. https://doi.org/10.1097/SLA.0b013e318248577d.

22. Baumgart J, Lang SA, Lang H. A new method for induction of liver hypertrophy prior to right trisectionectomy. HPB (Oxford). 2011; 13 Suppl 2:1-145. https://doi.org/10.1111/j.1477-2574.2011.00308.x.

23. de Santibanes E, Ardiles V, Alvarez FA. Associating Liver Partition and Portal Vein Ligation for Staged 
Hepatectomy: A Better Approach to Treat Patients With Extensive Liver Disease. JAMA Surg. 2015; 150:929-30. https://doi.org/10.1001/jamasurg.2015.1643.

24. Bertens KA, Hawel J, Lung K, Buac S, Pineda-Solis K, Hernandez-Alejandro R. ALPPS: challenging the concept of unresectability--a systematic review. Int J Surg. 2015; 13:280-7. https://doi.org/10.1016/j.ijsu.2014.12.008.

25. Torres OJ, Fernandes Ede S, Oliveira CV, Lima CX, Waechter FL, Moraes-Junior JM, Linhares MM, Pinto RD, Herman P, Machado MA. Associating liver partition and portal vein ligation for staged hepatectomy (ALPPS): the Brazilian experience. Arq Bras Cir Dig. 2013; 26:40-3.

26. Dokmak S, Belghiti J. Which limits to the "ALPPS" approach? Ann Surg. 2012; 256:e6; author reply e16-7. https://doi.org/10.1097/SLA.0b013e318265fd64.

27. Nadalin S, Capobianco I, Li J, Girotti P, Konigsrainer I, Konigsrainer A. Indications and limits for associating liver partition and portal vein ligation for staged hepatectomy (ALPPS). Lessons Learned from 15 cases at a single centre. Z Gastroenterol. 2014; 52:35-42. https://doi.org/10.1055/s-0033-1356364.

28. Truant S, Scatton O, Dokmak S, Regimbeau JM, Lucidi V, Laurent A, Gauzolino R, Castro Benitez C, Pequignot A, Donckier V, Lim C, Blanleuil ML, Brustia R, et al. Associating liver partition and portal vein ligation for staged hepatectomy (ALPPS): impact of the inter-stages course on morbi-mortality and implications for management. Eur J Surg Oncol. 2015; 41:674-82. https://doi.org/10.1016/j.ejso.2015.01.004.

29. Serenari M, Zanello M, Schadde E, Toschi E, Ratti F, Gringeri E, Masetti M, Cillo U, Aldrighetti L, Jovine E, Group AIR. Importance of primary indication and liver function between stages: results of a multicenter Italian audit of ALPPS 2012-2014. HPB (Oxford). 2016; 18:419 27. https://doi.org/10.1016/j.hpb.2016.02.003.

30. Petrowsky H, Gyori G, de Oliveira M, Lesurtel M, Clavien PA. Is partial-ALPPS safer than ALPPS? A single-center experience. Ann Surg. 2015; 261:e90-2. https://doi.org/10.1097/SLA.0000000000001087.

31. Tanaka K, Matsuo K, Murakami T, Kawaguchi D, Hiroshima Y, Koda K, Endo I, Ichikawa Y, Taguri M, Tanabe M. Associating liver partition and portal vein ligation for staged hepatectomy (ALPPS): short-term outcome, functional changes in the future liver remnant, and tumor growth activity. Eur J Surg Oncol. 2015; 41:506-12. https://doi.org/10.1016/j.ejso.2015.01.031.

32. Aloia TA. Associating Liver Partition and Portal Vein Ligation for Staged Hepatectomy: Portal Vein Embolization Should Remain the Gold Standard. JAMA Surg. 2015; 150:927-8. https://doi.org/10.1001/jamasurg.2015.1646.

33. Aloia TA, Vauthey JN. Associating liver partition and portal vein ligation for staged hepatectomy (ALPPS): what is gained and what is lost? Ann Surg. 2012; 256:e9; author reply e16-9. https://doi.org/10.1097/SLA.0b013e318265fd3e.
34. Hernandez-Alejandro R, Bertens KA, Pineda-Solis $\mathrm{K}$, Croome KP. Can we improve the morbidity and mortality associated with the associating liver partition with portal vein ligation for staged hepatectomy (ALPPS) procedure in the management of colorectal liver metastases? Surgery. 2015; 157:194-201. https://doi.org/10.1016/j.surg.2014.08.041.

35. Montalva Oron EM, Maupoey Ibanez J, Banuelos Carrillo R, Bosca Robledo A, Orbis Castellanos JF, Moya Herraiz A, Ballester Valles C, Perez Rojas J, Aparicio Urtasun J, Lopez-Andujar R. Monosegment ALPPS: A new variant of the techniques for rapid hepatic regeneration. Critical review of the initial results of our series. Cir Esp. 2015; 93:436-43. https://doi.org/10.1016/j.ciresp.2015.02.011.

36. Olthof PB, Coelen RJS, Wiggers JK, Groot Koerkamp B, Malago M, Hernandez-Alejandro R, Topp SA, Vivarelli M, Aldrighetti LA, Robles Campos R, Oldhafer KJ, Jarnagin WR, van Gulik TM. High mortality after ALPPS for perihilar cholangiocarcinoma: case-control analysis including the first series from the international ALPPS registry. HPB (Oxford). 2017; 19:381-7. https://doi.org/10.1016/j.hpb.2016.10.008.

37. Schadde E, Ardiles V, Robles-Campos R, Malago M, Machado M, Hernandez-Alejandro R, Soubrane O, Schnitzbauer AA, Raptis D, Tschuor C, Petrowsky H, De Santibanes E, Clavien PA, et al. Early survival and safety of ALPPS: first report of the International ALPPS Registry. Ann Surg. 2014; 260:829-36; discussion 36-8. https://doi.org/10.1097/SLA.0000000000000947.

38. D'Haese JG, Neumann J, Weniger M, Pratschke S, Bjornsson B, Ardiles V, Chapman W, Hernandez-Alejandro R, Soubrane O, Robles-Campos R, Stojanovic M, Dalla Valle R, Chan AC, et al. Should ALPPS be Used for Liver Resection in Intermediate-Stage HCC? Ann Surg Oncol. 2015; 23:1335-43. https://doi.org/10.1245/s10434-015-5007-0.

39. Linecker M, Stavrou GA, Oldhafer KJ, Jenner RM, Seifert B, Lurje G, Bednarsch J, Neumann U, Capobianco I, Nadalin S, Robles-Campos R, de Santibanes E, Malago M, et al. The ALPPS Risk Score: Avoiding Futile Use of ALPPS. Ann Surg. 2016; 264:763-71. https://doi.org/10.1097/sla.0000000000001914.

40. Robles R, Parrilla P, Lopez-Conesa A, Brusadin R, de la Pena J, Fuster M, Garcia-Lopez JA, Hernandez E. Tourniquet modification of the associating liver partition and portal ligation for staged hepatectomy procedure. Br J Surg. 2014; 101:1129-34; discussion 34. https://doi.org/10.1002/bjs.9547.

41. Linecker M, Kron P, Lang H, de Santibanes E, Clavien PA. Too Many Languages in the ALPPS: Preventing Another Tower of Babel? Ann Surg. 2016; 263:837-8. https://doi.org/10.1097/SLA.0000000000001632.

42. Llovet JM, Bru C, Bruix J. Prognosis of hepatocellular carcinoma: the BCLC staging classification. Semin Liver Dis. 1999; 19:329-38. https://doi.org/10.1055/s-2007-1007122. 
43. Sala S, Ardiles V, Ulla M, Alvarez F, Pekolj J, de Santibanes E. Our initial experience with ALPPS technique: encouraging results. Updates Surg. 2012; 64:167-72. https://doi.org/10.1007/s13304-012-0175-y.

44. Cavaness KM, Doyle MB, Lin Y, Maynard E, Chapman WC. Using ALPPS to induce rapid liver hypertrophy in a patient with hepatic fibrosis and portal vein thrombosis. J Gastrointest Surg. 2013; 17:207-12. https://doi.org/10.1007/s11605-012-2029-9.

45. Brustia R, Scatton O, Perdigao F, El-Mouhadi S, Cauchy F, Soubrane O. Vessel identifications tags for open or laparoscopic associating liver partition and portal vein ligation for staged hepatectomy. J Am Coll Surg. 2013; 217:e51-5. https://doi.org/10.1016/j.jamcollsurg.2013.08.020.

46. Chia NH, Lai EC, Lau WY. Associating liver partition and portal vein ligation for a patient with hepatocellular carcinoma with a background of hepatitis B related fibrotic liver. Int J Surg Case Rep. 2014; 5:1077-81. https://doi.org/10.1016/j.ijscr.2014.11.008.

47. Xiao L, Xiang LJ, Li JW, Chen J, Fan YD, Zheng SG. Laparoscopic versus open liver resection for hepatocellular carcinoma in posterosuperior segments. Surg Endosc. 2015; 29:2994-3001. https://doi.org/10.1007/s00464-015-4214-X.

48. Romic B, Romic I, Mance M, Pavlek G, Skegro M. Successful Associating Liver Partition and Portal Vein Ligation after Unsuccessful Double TACE Procedure Complicated with Sepsis and Pancreatitis. Klinicka Onkologie. 2016; 29:59-62.

49. Cheung TT, Wong TC, Chan SC. Technical note on ALPPS for a patient with advanced hepatocellular carcinoma associated with invasion of the inferior vena cava. Hepatobiliary Pancreat Dis Int. 2016; 15:319-23.

50. Torres OJ, Vasques RR, Silva TH, Castelo-Branco ME, Torres CC. The ALPPS procedure for hepatocellular carcinoma larger than 10 centimeters. Int J Surg Case Rep. 2016; 26:113-7. https://doi.org/10.1016/j.ijscr.2016.07.039.

51. de Santibanes E, Alvarez FA, Ardiles V, Pekolj J, de Santibanes M. Inverting the ALPPS paradigm by minimizing first stage impact: the Mini-ALPPS technique. Langenbecks Arch Surg. 2016; 401:557-63. https://doi.org/10.1007/s00423-016-1424-1.

52. Papamichail M, Pizanias M, Yip V, Prassas E, Prachalias A, Quaglia A, Peddu P, Heaton N, Srinivasan P. Associating liver partition and portal vein ligation for staged hepatectomy (ALPPS) procedure for hepatocellular carcinoma with chronic liver disease: a case report and review of literature. Korean J Hepatobiliary Pancreat Surg. 2016; 20:75-80. https://doi.org/10.14701/kjhbps.2016.20.2.75.

53. Hong de F, Zhang YB, Peng SY, Huang DS. Percutaneous Microwave Ablation Liver Partition and Portal Vein Embolization for Rapid Liver Regeneration: A Minimally Invasive First Step of ALPPS for Hepatocellular Carcinoma. Ann Surg. 2016; 264:e1-2. https://doi.org/10.1097/SLA.0000000000001707.
54. Chen JX, Ran HQ, Sun CQ. Associating microwave ablation and portal vein ligation for staged hepatectomy for the treatment of huge hepatocellular carcinoma with cirrhosis. Ann Surg Treat Res. 2016; 90:287-91. https://doi.org/10.4174/astr.2016.90.5.287.

55. Sanei B, Sheikhbahaei S, Sanei MH, Bahreini A, Jafari HR. Associating liver partition and portal vein ligation for staged hepatectomy: A surgical technique for liver resections. J Res Med Sci. 2017; 22:52. https://doi.org/10.4103/jrms.JRMS_829_16.

56. Alvarez FA, Ardiles V, de Santibanes M, Pekolj J, de Santibanes E. Associating liver partition and portal vein ligation for staged hepatectomy offers high oncological feasibility with adequate patient safety: a prospective study at a single center. Ann Surg. 2015; 261:723-32. https://doi.org/10.1097/sla.0000000000001046.

57. Vennarecci G, Grazi GL, Sperduti I, Busi Rizzi E, Felli E, Antonini M, D'Offizi G, Ettorre GM. ALPPS for primary and secondary liver tumors. Int J Surg. 2016; 30:38-44. https://doi.org/10.1016/j.ijsu.2016.04.031.

58. Chan AC, Poon RT, Chan C, Lo CM. Safety of ALPPS Procedure by the Anterior Approach for Hepatocellular Carcinoma. Ann Surg. 2016; 263:e14-6. https://doi.org/10.1097/sla.0000000000001272.

59. Bjornsson B, Sparrelid E, Hasselgren K, Gasslander T, Isaksson B, Sandstrom P. Associating Liver Partition and Portal Vein Ligation for Primary Hepatobiliary Malignancies and Non-Colorectal Liver Metastases. Scand J Surg. 2016; 105:158-62. https://doi.org/10.1177/1457496915613650.

60. Chan AC, Chok K, Dai JW, Lo CM. Impact of split completeness on future liver remnant hypertrophy in associating liver partition and portal vein ligation for staged hepatectomy (ALPPS) in hepatocellular carcinoma: Complete-ALPPS versus partial-ALPPS. Surgery. 2017; 161:357-64. https://doi.org/10.1016/j.surg.2016.07.029.

61. Wang Q, Yan J, Feng X, Chen G, Xia F, Li X, Ma K, Bie P. Safety and efficacy of radiofrequency-assisted ALPPS (RALPPS) in patients with cirrhosis-related hepatocellular carcinoma. Int J Hyperthermia. 2017; 33:846-852. https://doi.org/10.1080/02656736.2017.1303752.

62. Cai X, Tong Y, Yu H, Liang X, Wang Y, Liang Y, Li $Z$, Peng S, Lau WY. The ALPPS in the Treatment of Hepatitis B-Related Hepatocellular Carcinoma With Cirrhosis: A Single-Center Study and Literature Review. Surgical Innovation. 2017; 24:358-64. https://doi.org/10.1177/1553350617697187.

63. Schadde E, Raptis DA, Schnitzbauer AA, Ardiles V, Tschuor C, Lesurtel M, Abdalla EK, Hernandez-Alejandro R, Jovine E, Machado M, Malago M, Robles-Campos R, Petrowsky H, et al. Prediction of Mortality After ALPPS Stage-1: An Analysis of 320 Patients From the International ALPPS Registry. Ann Surg. 2015; 262:780-5; discussion 5-6. https://doi.org/10.1097/sla.0000000000001450.

64. Troja A, Khatib-Chahidi K, El-Sourani N, Antolovic D, Raab HR. ALPPS and similar resection procedures in 
treating extensive hepatic metastases: our own experiences and critical discussion. Int J Surg. 2014; 12:1020-2. https://doi.org/10.1016/j.ijsu.2014.07.006.

65. Oldhafer F, Ringe KI, Timrott K, Kleine M, Ramackers W, Cammann S, Jager MD, Klempnauer J, Bektas H, Vondran FW. Intraoperative Conversion to ALPPS in a Case of Intrahepatic Cholangiocarcinoma. Case Rep Surg. 2015; 2015:273641. https://doi.org/10.1155/2015/273641.

66. Vicente E, Quijano Y, Ielpo B, Duran H, Diaz E, Fabra I, Olivares S, Prestera A, Caruso R. Is "small for size syndrome" a relatively new complication after the ALPPS procedure? Updates Surg. 2015; 67:273-8. https://doi.org/10.1007/s13304-015-0300-9.

67. Lau WY, Lai EC, Lau SH. Associating liver partition and portal vein ligation for staged hepatectomy: the current role and development. Hepatobiliary Pancreat Dis Int. 2017; 16:17-26.

68. Pineda-Solis K, Paskar D, Tun-Abraham M, HernandezAlejandro R. Expanding the limits of resectability: Associating liver partition and portal vein ligation for staged hepatectomy (ALPPS) using monosegment 6, facilitated by an inferior right hepatic vein. J Surg Oncol. 2017; 115:95962. https://doi.org/10.1002/jso.24604.

69. Oldhafer KJ, Stavrou GA, van Gulik TM, Core G. ALPPS-Where Do We Stand, Where Do We Go?: Eight Recommendations From the First International Expert Meeting. Ann Surg. 2016; 263:839-41. https://doi.org/10.1097/SLA.0000000000001633.

70. Sakamoto Y, Matsumura M, Yamashita S, Ohkura N, Hasegawa K, Kokudo N. Partial TIPE ALPPS for Perihilar Cancer. Ann Surg. 2018; 267:e18-e20. https://doi.org/10.1097/sla.0000000000002484.

71. Llovet JM, Ricci S, Mazzaferro V, Hilgard P, Gane E, Blanc JF, de Oliveira AC, Santoro A, Raoul JL, Forner A, Schwartz M, Porta C, Zeuzem S, et al. Sorafenib in advanced hepatocellular carcinoma. N Engl J Med. 2008; 359:378-90. https://doi.org/10.1056/NEJMoa0708857.

72. Wang Y, Yuan L, Ge RL, Sun Y, Wei G. Survival benefit of surgical treatment for hepatocellular carcinoma with inferior vena cava/right atrium tumor thrombus: results of a retrospective cohort study. Ann Surg Oncol. 2013; 20:91422. https://doi.org/10.1245/s10434-012-2646-2.

73. European Association For The Study Of The Liver; European Organisation For Research And Treatment Of Cancer. EASL-EORTC clinical practice guidelines: management of hepatocellular carcinoma. J Hepatol. 2012; 56:908-43. https://doi.org/10.1016/j.jhep.2011.12.001.

74. Manzini G, Henne-Bruns D, Porzsolt F, Kremer M. Is there a standard for surgical therapy of hepatocellular carcinoma in healthy and cirrhotic liver? A comparison of eight guidelines. BMJ Open Gastroenterol. 2017; 4:e00129. https://doi.org/10.1136/bmjgast-2016-000129.

75. de Santibañes E, Alvarez F, Ardiles V, de Santibañes M, Pelj J. Inverting the ALPPS paradigm by minimizing first stage impact: The mini-ALPPS. HPB. 2015; 18:e119. https://doi.org/10.1016/j.hpb.2016.02.278.

76. Linecker M, Kambakamba P, Reiner CS, Linh NguyenKim TD, Stavrou GA, Jenner RM, Oldhafer KJ, Bjornsson B, Schlegel A, Gyori G, Schneider MA, Lesurtel M, Clavien PA, et al. How much liver needs to be transected in ALPPS? A translational study investigating the concept of less invasiveness. Surgery. 2017; 161:453-64. https://doi.org/10.1016/j.surg.2016.08.004.

77. Linecker $\mathrm{M}$, Bjornsson B, Stavrou GA, Oldhafer KJ, Lurje G, Neumann U, Adam R, Pruvot FR, Topp SA, Li J, Capobianco I, Nadalin S, Machado MA, et al. Risk Adjustment in ALPPS Is Associated With a Dramatic Decrease in Early Mortality and Morbidity. Ann Surg. 2017; 266:779-86. https://doi.org/10.1097/sla.0000000000002446.

78. Lau WY, Lai EC. Modifications of ALPPS - from complex to more complex or from complex to less complex operations. Hepatobiliary Pancreat Dis Int. 2017; 16:34652. https://doi.org/10.1016/s1499-3872(17)60034-1.

79. Xiao L, Li JW, Zheng SG. Totally laparoscopic ALPPS in the treatment of cirrhotic hepatocellular carcinoma. Surg Endosc. 2015; 29:2800-1. https://doi.org/10.1007/s00464-014-4000-1.

80. Mansour JC, Aloia TA, Crane CH, Heimbach JK, Nagino M, Vauthey JN. Hilar cholangiocarcinoma: expert consensus statement. HPB (Oxford). 2015; 17:691-9. https://doi.org/10.1111/hpb.12450.

81. Forsmark CE, Diniz AL, Zhu AX. Consensus conference on hilar cholangiocarcinoma. HPB (Oxford). 2015; 17:666-8. https://doi.org/10.1111/hpb.12451.

82. von Elm E, Altman DG, Egger M, Pocock SJ, Gøtzsche PC, Vandenbroucke JP; STROBE Initiative. The Strengthening the Reporting of Observational Studies in Epidemiology (STROBE)statement: guidelines for reporting observational studies. Journal of Clinical Epidemiology. 2008; 61:344-9.

83. Shea BJ, Grimshaw JM, Wells GA, Boers M, Andersson N, Hamel C, Porter AC, Tugwell P, Moher D, Bouter LM. Development of AMSTAR: a measurement tool to assess the methodological quality of systematic reviews. BMC Med Res Methodol. 2007; 7:10.

84. Higgins JP, Altman DG, Gøtzsche PC, Jüni P, Moher D, Oxman AD, Savovic J, Schulz KF, Weeks L, Sterne JA; Cochrane Bias Methods Group; Cochrane Statistical Methods Group. The Cochrane Collaboration's tool for assessing risk of bias in randomised trials. BMJ. 2011; 343:d5928. https://doi.org/10.1136/bmj.d5928.

85. Glantzounis GK, Tokidis E, Basourakos SP, Ntzani EE, Lianos GD, Pentheroudakis G. The role of portal vein embolization in the surgical management of primary hepatobiliary cancers. A systematic review. Eur J Surg Oncol. 2017; 43:32-41. https://doi.org/10.1016/j.ejso.2016.05.026. 
86. Dindo D, Demartines N, Clavien PA. Classification of Surgical Complications. Annals of Surgery. 2004; 240:20513. https://doi.org/10.1097/01.sla.0000133083.54934.ae.

87. Rahbari NN, Garden OJ, Padbury R, Brooke-Smith M, Crawford M, Adam R, Koch M, Makuuchi M,
Dematteo RP, Christophi C, Banting S, Usatoff V, Nagino $M$, et al. Posthepatectomy liver failure: a definition and grading by the International Study Group of Liver Surgery (ISGLS). Surgery. 2011; 149:713-24. https://doi.org/10.1016/j.surg.2010.10.001. 